\title{
PELATIHAN PENGOLAHAN AIR DALAM MENGATASI KRISIS AIR BERSIH
}

\section{WATER TREATMENT TRAINING IN OVERCOMING CLEAN WATER CRISIS}

\author{
${ }^{1)}$ Muh. Fajaruddin Natsir, ${ }^{2)}$ Makmur Selomo, ${ }^{3)}$ Muh. Asfar \\ ${ }^{1,2}$ Jurusan Kesehatan Lingkungan, Fakultas Kesehatan Masyarakat Universitas Hasanuddin \\ Makassar, \\ ${ }^{3}$ Jurusan Ilmu dan Teknologi Pangan, Fakultas Pertanian, Universitas Hasanuddin Makassar, \\ Jl. Perintis Kemerdekaan Km. 10 Tamalanrea, 90245 \\ Email: ahmadfajarislam@gmail.com
}

\begin{abstract}
ABSTRAK
Kelurahan Untia terletak di wilayah timur Makassar dan sering mengalami krisis air bersih. Selain itu, masalah yang lain adalah rendahnya kualitas air sumur gali yang merupakan sumber air utama dari masyarakat Kelurahan Untia. Tujuan kegiatan ini adalah untuk memberikan pelatihan kepada masyarakat di Kelurahan Untia dalam pengolohan air. Kegiatan pengabdian dilakukan dimulai dengan tahap persiapan, sosialisasi, pelatihan pengolahan air, dan pendampingan pembuatan alat pengolahan air bersih. Hasil kegiatan pengabdian ini adalah meningkatnya pengetahuan masyarakat $(p=0,000<0,05)$ mengenai pengolahan air sebelum penyuluhan dengan sesudah penyuluhan.Selain itu dihasilkan contoh alat pengolahan air bersih yang di pasang di masjid Nurul Hijrah.
\end{abstract}

Kata kunci: Air Bersih; Pengolahan Air; Filtrasi

\section{ABSTRACT}

Untia Urban Village is located in the eastern part of Makassar and often experiences a clean water crisis. Besides, another problem is the low quality of dug well water which is the primary water source of the Untia village community. The purpose of this activity is to provide training to the community in Untia Village in water collection. Community service activities begin with the preparation, outreach, training on water treatment, and assistance in the manufacture of clean water treatment equipment. The results of this community service activity are increasing public knowledge $(p=0,000<0.05)$ regarding water treatment before counseling and after counseling. Also, examples of clean water treatment equipment are installed in the Nurul Hijrah mosque.

Keywords: Clean Water; Water treatment; Filtration

\section{PENDAHULUAN}

Biringkanya merupakan salah satu kecamatan yang ada di Makassar Provinsi Sulawesi Selatan. Kecamatan Biringkanaya terdiri dari 7 kelurahan yaitu Kelurahan Sudiang, Sudiang Raya, Pai, Bulurokeng, Paccerakkang, Daya, danUntia. Data dari kecamatan menyebutkan bahwa jumlah Kepala Keluarga (KK) diKecamatan
Biringkanaya sebanyak 39.646 kepala keluarga.

Dalam mencukupi kebutuhan seharihari dalam hal sumber daya air,masyarakat di Kecamatan Biringkanaya sebagian besar telah menggunakan fasilitas air bersih sumur bor dan pelayanan air bersih dari Perusahaan Daerah Air Minum (PDAM), namun ada juga masyarakat yang masih 
menggunakan sumurgali atau sumur dangkal sebagai sumber air bersih, salah satu alasannya karenapelayanan air bersih dari PDAM belum sepenuhnya menjangkau seluruh daerahdi Kecamatan Biringkanaya, sedangkan penggunaan sumur bor tidakmemungkinkan dari segi biaya bagi sebagian masyarakat kecil. Hal ini dialami terutama di Kelurahan Untia, yang merupakan wilayah pesisir Kota Makassar.

Kelurahan Untia memiliki luas 2,89 $\mathrm{km}^{2}$ dengan jumlah penduduk 2.080 jiwa. Masyarakat yang ada di Kelurahan Untia sering mengalami krisis air bersih. Pada tahun 2016, warga di Kelurahan Untia harus antri berjam-jam untuk mendapatkan air bersih, itupun melalui mobil tangki air yang mengantar ke wilayah tersebut.

Kelurahan Untia memiliki luas 2,89 $\mathrm{km}^{2}$ dengan jumlah penduduk 2.080 jiwa. Masyarakat yang ada di Kelurahan Untia sering mengalami krisis air bersih. Pada tahun 2016, warga di Kelurahan Untia harus antri berjam-jam untuk mendapatkan air bersih, itupun melalui mobil tangki air yang mengantar ke wilayah tersebut(Hadi, 2016)

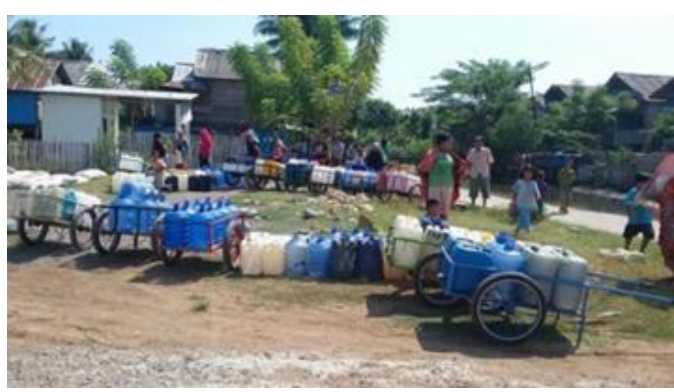

Gambar 1. Antrian Air Bersih

Menurut Kepala PDAM Wilayah Timur Makassar, PDAM kesulitan menjangkau wilayah Kelurahan Untia yang merupakan daerah terjauh di wilayah timur Makassar. Sehingga terkadang aliran air di Kima tidak dapat menjangkau daerah tersebut.

Sumber air bersih dari masyarakat Kelurahan Untia adalah dari sumur gali.
Di antara sumurgali yang terdapat di Wilayah tersebut terdapat beberapa sumur gali yangtiap sumurnya digunakan oleh 3 sampai 4 rumah tangga. Selain karena masalah krisis air bersih di wilayah Kelurahan Untia, yang menjadipermasalahan juga adalah masyarakat sekitar tidak tahu air sumur tersebut layak atautidak digunakan sebagai sumber air bersih untuk kebutuhan sehari-hari.

Jumlah sumur gali yang terdapat di Kelurahan Untia berjumlah 11 sumur. Hasil analisis kualitas air sumur gali diwilayah Kelurahan Untia didapatkan bahwa beberapa parameter belum memenuhi syarat yang diperbolehkan. Hasil pengukuran air sumur gali untuk parameter fisik, yaitu kekeruhan 11,16 NTU, warna 15 TCU, TSS 9 mg/L. Hasil pengukuran parameter kimia yaitu, besi $0,3188 \mathrm{mg} / \mathrm{L}$, kesadahan 68,9 $\mathrm{mg} / \mathrm{L}$, mangan $0,5416 \mathrm{mg} / \mathrm{l}$, BOD $5 \mathrm{mg} / \mathrm{l}$, COD $2744 \mathrm{mg} / \mathrm{l}$. Sedangkan untuk parameter biologi hasil pengukuran MPN Coliform yaitu >1600 MPN/100 mL, lebih dari standar yang diperbolehkan yaitu $<50$ MPN/100mL(SURYANA, 2013).

Rendahnya kualitas air sumur gali pada yang dimiliki oleh masyarakat Kelurahan Untia menyebabkan perlunya dilakukan pengolahan air terlebih dahulu sebelum digunakan. Metode pengolahan air bersih yang bisa digunakan dengan cara fisik adalah filtrasi(Fatimah \& Wijaya, 2005; Nasik, 2015; Saputra, 2006).

Filtrasi adalah proses pengolahan air dengan mengalirkan air ke media untuk menghilangkan partikel padat yang ada pada air tersebut. Media yang biasa digunakan pada proses filtrasi adalah zeolite dan carbon.

Penggunaan zeolit dan karbon aktif dalam pengolahan air telah banyak digunakan. Dari hasil penelitian diketahui bahwa variasi campuran dengan komposisi $75 \%$ zeolit aktif dan $25 \%$ karbon aktif dalam mengolah air payau mempunyai efisiensi penurunan yang 
baik,yaitu mampu menurunkan kadar besi sebesar 67\%, kadar klorida 65\% dan kadar TDS 63\%(Purwoto \& Nugroho, 2013)

Berdasarkan penjelasan di atas, yang menjadi tujuan dalam kegiatan pengabdian ini adalah meningkatkan kemampuan masyarakat dalam pengolahan air bersih dengan metode filtrasi menggunakan zeolit dan karbin aktif.

\section{METODE}

Mitra dalam kegiatan pengabdian ini adalah pengurus masjid Nurul Hijrah Kelurahan Untia Kecamatan Biringkanaya Makassar. Peran mitra dalam kegiatan pengabdian ini, selain sebagai peserta pelatihan dan penyuluhan, juga bersama dengan tim dalam membuat alat pengolahan air bersih dengan metode filtrasi.

Tahapan pelaksanaan pada kegiatan pengabdian ini adalah:

\section{a. Sosialisasi dan FGD}

Pada tahapan ini Tim melakukan sosialisasi kegiatan serta melakukan FGD ke pengurus masjid dan tokoh masysarakat mengenai masalah air bersih di wilayahnya.

b. Pembuatan alat pengolahan air bersih

Pada tahapan ini, tim bersama pengurus masjid membuat alat pengolahan air dengan metode filtrasi yang dipasang ditempat wudhu masjid.

c. Penyuluhan dan Pelatihan pengolahan air

Peserta pelatihan pada kegiatan pengabdian ini berjumlah lebih dari 35 orang warga yang merupakan jamaah masjid Nurul Hijrah. Pengurus masjid dipilih menjadi peserta pelatihan karena contoh alat pengolahan air bersih akan dipasang di masjid ini sehingga mereka akan mengetahui proses perawatan alat pengolahan air.

\section{HASIL DAN PEMBAHASAN}

Kegiatan ini dimulai dari persiapan, sosialisasi, pembuatan alat dan penyuluhan serta pelatihan pengolahan air bersih.

Pembuatan alat pengolahan air dilaksanakan bersama-sama dengan warga. Metode pengolahan air bersih yang digunakan adalah metode filtrasi menggunakan media zeolit, karbon aktif dan pasir mangan.

Sebelum dilakukan pembuatan alat, terlebih dahulu tim bersama dengan masyarakat memperbaiki pipa air sumur masjid. Pipa penghisap di bagian bawah sumur dipasangkan pipa yang dilapisi ijuk. Ijuk ini berguna sebagai penyaring awal air sumur sebelum masuk filtrasi.

Penelitian terkait ijuk dalam pengolahan air bersih telah banyak dilakukan. Pengolahan air yang menggokombinasikan arang aktif (ketebalan $30 \mathrm{~cm}$ ) dan ijuk (ketebalan 30 $\mathrm{cm}$ ) dengan waktu kontak 6 menit mampu menurunkan kadar besi yang sebelumnya $8 \mathrm{mg} / \mathrm{L}$ menjadi $0,3 \mathrm{mg} / \mathrm{l}$ (Sujarwanto, 2014).

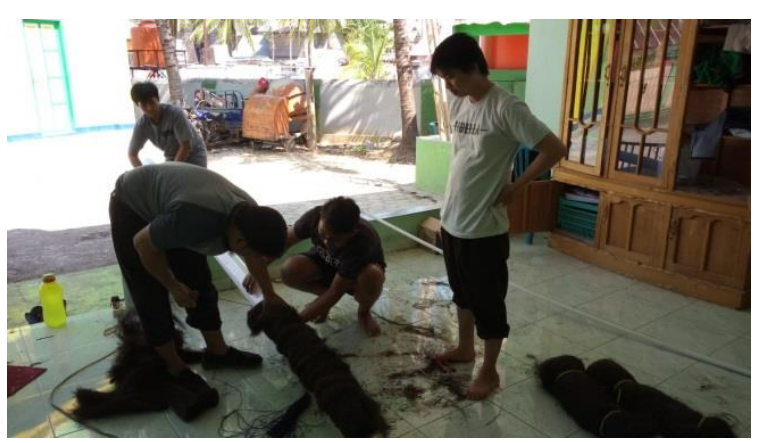

Gambar 2. Pemasangan ijuk

Setelah pemasangan ijuk pada pipa penghisap sumur, dilakukan pemasangan alat pengolahan air bersih dengan metode filtrasi. Air sumur masjid Nurul Hijrah Kelurahan Untia memiliki kualitas yang rendah, sehingga belum layak digunakan untuk berwudhu. Filter yang digunakan 
berisi karbon aktif, zeolite dan pasir mangan.

Zeolit dan karbon aktif juga efektif digunakan untuk menurunkan kesadahan air sumur gali. Penelitian yang dilakukan di Desa Karangtengah Kecamatan Weru Kabupaten Sukoharjo yang menggunakan media zeolit dan karbon aktif dalam menurunkan kesadahan air sumur gali mendapatkan bahwa ketebalan $70 \mathrm{~cm}$ mampu menurunkan kesadahan yang sebelumnya $557,14 \mathrm{mg} / \mathrm{L}$ menjadi 31,43 $\mathrm{mg} / \mathrm{L}$ (Ristiana, Astuti, \& Kurniawan, 2009).

Penelitian lain yang menggunakan zeolit dan karbon aktif pada pengolahan air tanah mendapatkan hasil bahwa perbandingan zeolit dan karbon aktif 30 $\mathrm{cm}$ dan $60 \mathrm{~cm}$ mampu menyisihkan zat kapur sebesar 96,52 \%(Dinora \& Purnomo, 2013).

Hasil pengolahan air setelah memasuki filter telah menjadi bersih dan dapat digunakan untuk berwudhu.

Bentuk kegiatan pengabdian ini juga berupa penyuluhan dan pelatihan pengolahan air secara sederhana.Kegiatan ini penyuluhan dan pelatihan ini dilakukan di dalam masjid Nurul Hijrah.

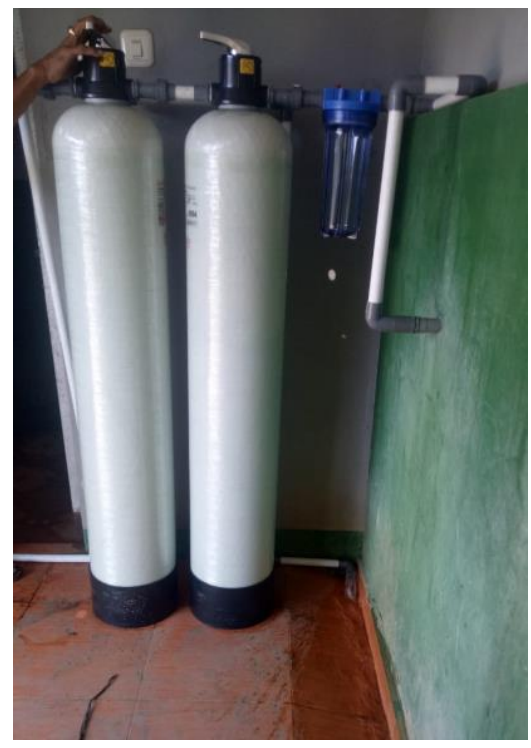

Gambar 3. Alat filtrasi yang dipasang di tempat wudhu
Materi yang disajikan pada penyuluhan ini menjelaskan mengenai ayat di dalam Al-Qur'an mengenai air, peranan air dalam kehidupan, penyakit yang ditularkan melalui air, panen air hujan, serta pengolahan air dengan cara filtrasi, Reverse Osmosis, dan secara sederhana.

Untuk mengukur peningkatan pengetahuan peserta penyuluhan, maka setiap peserta diberikan pre dan post test sebelum dan setelah penyuluhan. Distribusi tingkat pengetahuan responden sebelum dan setelah penyuluhan dapat dilihat pada tabel berikut :

Tabel 1. Distribusi Tingkat Pengetahuan Responden Sebelum dan Sesudah Penyuluhan Tahun 2018

\begin{tabular}{|c|c|c|c|c|c|}
\hline \multirow{2}{*}{$\begin{array}{c}\text { Tingkat } \\
\text { Pengetahuan }\end{array}$} & \multicolumn{2}{|c|}{ Pre-test } & \multicolumn{2}{|c|}{ Post-tes } & \multirow{2}{*}{$\begin{array}{c}\text { Nilai } \\
\mathbf{p}\end{array}$} \\
\hline & $\mathbf{n}$ & $\%$ & $\mathbf{N}$ & $\%$ & \\
\hline $\begin{array}{c}\text { Pengetahuan } \\
\text { rendah }\end{array}$ & 12 & $\begin{array}{c}34, \\
3\end{array}$ & 2 & 5,7 & \multirow{4}{*}{$\begin{array}{c}0,000 \\
(\mathrm{p}< \\
0,05)\end{array}$} \\
\hline $\begin{array}{l}\text { Pengetahuan } \\
\text { sedang }\end{array}$ & 20 & $\begin{array}{c}57, \\
1\end{array}$ & $\begin{array}{l}2 \\
4\end{array}$ & $\begin{array}{c}68, \\
6\end{array}$ & \\
\hline $\begin{array}{c}\text { Pengetahuan } \\
\text { tinggi }\end{array}$ & 3 & 8,6 & 9 & $\begin{array}{c}25 \\
7\end{array}$ & \\
\hline Total & 35 & 100 & $\begin{array}{l}3 \\
5\end{array}$ & 100 & \\
\hline
\end{tabular}

Sumber : Data Primer

Tabel 1 menunjukkan bahwa terjadi peningkatan jumlah responden dengan pengetahuan tinggi setelah penyuluhan, yaitu dari 8,6 \% menjadi 25,7 \%. Sedangkan jumlah responden yang pengetahuan kurang menurun dari 34,3\% menjadi 5,7\% setelah penyuluhan.

Berdasarkan tabel hasil analisis uji Wilcoxon, terlihat bahwa nilai $\mathrm{p}=0,000<$ 0,05 yang artinya ada perbedaan antara pengetahuan responden tentang pengolahan air sebelum penyuluhan dengan sesudah penyuluhan.Warga sangat antusias mengikuti kegiatan penyuluhan 
dan pelatihan terbukti dari banyak pertanyaan terkait materi yang diberikan.

Hasil ini sejalan dengan penelitian di Kabupaten Samosir yang menyatakan bahwa ada hubungan antara penyuluhan terhadap pengetahuan dan sikap masyarakat tentang pengolahan air permukaan dengan menggunakan saringan air sederhana (Manik, 2018).

\section{SIMPULAN}

Hasil kegiatan dapat disimpulkan : Para mitra yaitu masyarakat kelurahan Untia mampu melakukan pengolahan air bersih dan mengetahui peranan air bagi kehidupan serta penyakit-penyakit yang ditularkan melalui air.

\section{UCAPAN TERIMAKASIH}

Dalam pengabdian ini, penulis banyak memperoleh petunjuk dan bimbingan dari berbagai pihak. Sehubungan dengan hal tersebut,pada kesempatan ini penulis menyampaikan ucapan terimakasih kepada Pengurus masjid, serta Masyarakat kelurahan Untia, karena telah menerima, mengizinkan dan membantu terselenggaranya pelatihan pengolahan air bersih serta rekan-rekan yang telah membantu dan mendukung kegiatan pengabdian ini.

\section{DAFTAR PUSTAKA}

Dinora, G. Q., \& Purnomo, A. (2013). Penurunan Kandungan Zat Kapur dalam Air Tanah dengan Menggunakan Media Zeolit Alam dan Karbon Aktif Menjadi Air Bersih. Jurnal Teknik ITS, 2(2), D78-D82.

Fatimah, I., \& Wijaya, K. (2005). Sintesis TiO2/zeolit sebagai fotokatalis pada pengolahan limbah cair industri tapioka secara adsorpsifotodegradasi. Jurnal Teknoin, 10(4).
Hadi, A. (2016). Kodong, Warga Salodong Harus Antri Berjamjam Untuk Dapat Air Bersih. Retrieved 21 Maret, 2017, from https://v1.makassarterkini.com/ko dong-warga-salodong-harus-antriberjam-jam-untuk-dapat-airbersih/

Manik, E. (2018). Pengaruh Penyuluhan Terhadap Pengetahuan Dan Sikap Masyarakat Tentang Pengolahan Air Permukaan Menggunakan Saringan Air Sederhana Di Dusun I Desa Ronggurnihuta Kabupaten Samosir Tahun 2017. Karya Tulis Ilmiah, Poltekkes Kemenkes RI Medan

Nasik. (2015). Studi Pengolahan Limbah cair tahu dengan menggunakan koagulan PAC (Poly alumunium Chloride) dan Flokulan organoclay (BentonitPolydadmac). Skripsi, Universitas Negeri Islam Sunan Kalijaga, Sleman.

Purwoto, S., \& Nugroho, W. (2013). Removal Klorida, TDS dan Besi pada Air Payau melalui Penukar Ion dan Filtrasi Campuran Zeolit Aktif dengan Karbon Aktif. WAKTU, 11(1), 47-59.

Ristiana, N., Astuti, D., \& Kurniawan, T. P. (2009). Keefektifan ketebalan kombinasi zeolit dengan arang aktif dalam menurunkan kadar kesadahan air sumur di Karangtengah Weru Kabupaten Sukoharjo. Jurnal Kesehatan, 2, (1), 91-102

Saputra, R. (2006). Pemanfaatan zeolit sintetis sebagai alternatif pengolahan limbah industri. Buletin IPT, 1, 8-20. 
Sujarwanto, A., (2014). Keefektifan

Media Filter Arang Aktif dan Ijuk Dengan Variasi Lama Kontak

Dalam Menurunkan Kadar Besi Air Sumur di Pabelan Kartasura Sukoharjo. Skripsi, Universitas Muhammadiyah Surakarta.

Suryana, R. (2013). Analisis Kualitas Air Sumur Dangkal Di Kecamatan Biringkanayya Kota Makassar. Tugas Akhir, Jurusan Sipil, Fakultas Teknik, Univesitas Makasar 